\title{
To take a second look at Malachi the book
}

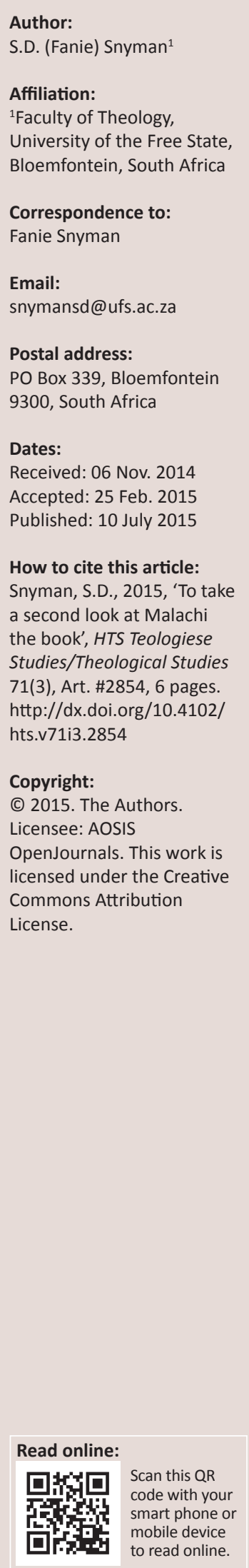

An investigation into some of the literary features of the book of Malachi reveals that each unit is structured in a twofold way. The macrostructure of the book also shows that the book can be divided into two parts. The results of this investigation strengthens the recent trend in the research of Malachi that it is unlikely that the book underwent an extensive redactional process over a period of time and that it is rather more likely that the book was written in a relatively short period of time.

\section{Introduction}

Research on the book of Malachi has been enriched by a number of commentaries, as well as several articles and contributions in books that have been published over the last few years (cf. Assis 2010; Kessler 2011; Meinhold 2006; Willi-Plein 2007). Although many and detailed studies have been done, one of the issues that is still in need of more attention is the question of the composition of the different units that make up the book. How and in what way are the different pericopes or units of the book of Malachi structured? Do the different units display a particular and similar structure? If so, what bearing will that have on the understanding of the book as a whole? This contribution views the book as a whole and argues that the different units of the book are structured in such a way as to display a double or twofold structure.

In what follows, the basic methodological point of departure will be explained, followed by an overview of recent research on the question put in this article. After a unit-by-unit investigation of the book of Malachi to illustrate the twofold structure displayed in each unit, the macrostructure of the book will be considered before some conclusions will be drawn.

\section{Methodological considerations}

The hypothesis that each unit of the book consists of two parts will be argued in a unit-by-unit discussion. This investigation views the text from a literary point of view taking the final form of the text as the point of departure paying special attention to literary devices (inclusio, chiasm) employed in the text and will therefore not consider the possible growth of the text over a period. In the past Malachi was subjected to historical critical analyses that resulted in the book being considered as originating over a lengthy period. Recent research differs from that opinion in that the book is seen as written over a short period. Hieke (2006:12), for instance, notes that it is a current trend in the research on the book to view it as a book that 'weitgehend als einheitlich angesehen werden kann'. However, the superscription (Ml 1:1) and the postscript (Ml 3:22-24) are regarded as later redactional additions to the original book. Minor additions (cf. Ml 2:2; 3:1a) may also be detected, but largely the book as we have it can be seen as a book with little evidence of extensive redactional editing.

\section{Recent research on the structure of the book as a whole}

Space does not allow a comprehensive review of past attempts to establish the overall structure of the book as a whole. Two recent contributions in this regard are worth mentioning. The investigation by Assis (2010:363) resulted in viewing the book as consisting of two parts each consisting of three units each: Malachi 1:2-9; 1:10-2:9;2:10-16 and then 2:17-3:6;3:7-12 and 3:13-21. Kessler's (2011:53) contribution resulted in the following structure: Malachi 1:2-5 is seen as foundational to the book. It is followed by two units $(1: 6-2: 9 ; 2: 10-16)$ characterised as critique voiced by the prophet; followed in turn by the next two units $(2: 17-3: 5 ; 3: 6-12)$ characterised by a view to the future. The last unit (3:13-21; English 3:13-4:3) provides the aim of the book as a whole. From this analysis the third (2:10-16) and fourth (2:17-3:5) units form the centre of the book. 


\section{Taking a second look at the book Malachi 1:1 superscription}

Malachi 1:1 forms the superscription of the book similar but not identical to the other superscriptions found in the so called Major Prophets (Is 13:1; 14:28; 15:1; 17:1; 19:1; 21:1, 11, $13 ; 22: 1 ; 23: 1 ; 30: 6$; Ezk 12:10) as well as in the Book of the Twelve (Nah 1:1; Hab 1:1; Zch 9:1; 12:1). The superscription displays a twofold content: the book is first of all characterised as a massa' (משא). Some think of massa' (משא) in terms of 'verdict' or 'sentence' meaning judgement upon the people (De Boer 1948:197-214), but this is probably too narrow an interpretation of the word. In an extended sense it also got the meaning of 'message', 'pronouncement', 'announcement', 'utterance', 'proclamation' or 'oracle'. Perhaps it was thought that for a prophet to announce the word of $\mathrm{YHWH}$ was a burden to be delivered to the hearers of the utterance.

The second part of the heading informs the reader that what follows now is also a word of $\mathrm{YHWH}$ to Israel from the hand of Malachi ${ }^{1}$. Three possible relationships between massa' (משא) and 'a word of YHWH' have been proposed. It may be understood as a genitive relationship resulting in a translation that connects the two phrases closely (Baldwin 1978; Rudolph 1976): 'the oracle of the word of the Lord' as RSV did. A second possibility is to regard the relationship as an appositional one resulting in a translation like the NIV: 'An oracle: The word of the Lord...' (Elliger 1975:189; Ridderbos 1935:199). A third possibility is to keep the two phrases apart and to interpret it as two distinct utterances on what the rest of the book will consist of. Considering the fact that massa' (משא) occurs frequently as a heading in other prophetic books, the last option is the favoured one (Horst 1964; Smith 1980; Van der Woude 1982).

Whereas massa' (משא) is an indication of the tone of what may be expected in the book (it is a prophetic announcement), the next phrase debar yhwh (רבד יהוה) characterises the content of the book as a word from YHWH, indicating nothing other than divine revelation. Willi-Plein (2007:233) also noticed the twofold introduction to the book when she states: 'Die Überschrift eröffnet das Gesamtbuch und klazzifiziert es zunächst zwiefach: Als "Lastwort" und als "Wort" JHWHs'.

\section{Malachi 1:2-5 Jacob and Esau}

The first unit in the book is programmatic for what follows in the rest of the book. The book opens with a proclamation of YHWH's love for his people. His love for his people is motivated by contrasting the twin brothers dating back to ancestral times, Jacob and Esau. Once again the author/ redactor made use of a twofold way to make his point. On the one hand the love YHWH has for Jacob/Israel is stated. At the same time YHWH's attitude towards Esau/Edom is also stated. This twofold character of the unit is illustrated by a chiastic pattern contrasting Jacob/Israel and Esau/Edom.

1.Whether or not the term malaki is seen as a proper noun or not is not part of this discussion.
The macrostructure of the pericope reveals a chiasm (Snyman 1986:436-438):

- In the first chiasm the love YHWH (A) has for Israel (B) is stated.

- In the second chiasm YHWH's love for Jacob (B) is contrasted with his hate for Esau (C).

- In the last chiasm what Edom's (C) intentions are set over against what $\mathrm{YHWH}(\mathrm{A})$ intends to do.

The first chiasmus (v. 2) deals with the relationship between YHWH and Israel. The second chiasmus (vv. 2-3) has to do with YHWH's love for Jacob/Israel in contrast with Esau/ Edom. The third chiasmus deals with Edom's intended actions and YHWH's response (v. 4). The following pattern arises: (A) YHWH (B) Jacob/Israel, (B) Jacob (C) Esau, (C) Esau/Edom (A) YHWH. It all amounts to a chiastic pattern of A (YHWH) BB (Jacob/Israel) CC (Esau/Edom) $\mathrm{A}(\mathrm{YHWH})$.

Graphically it can be illustrated in the following way:
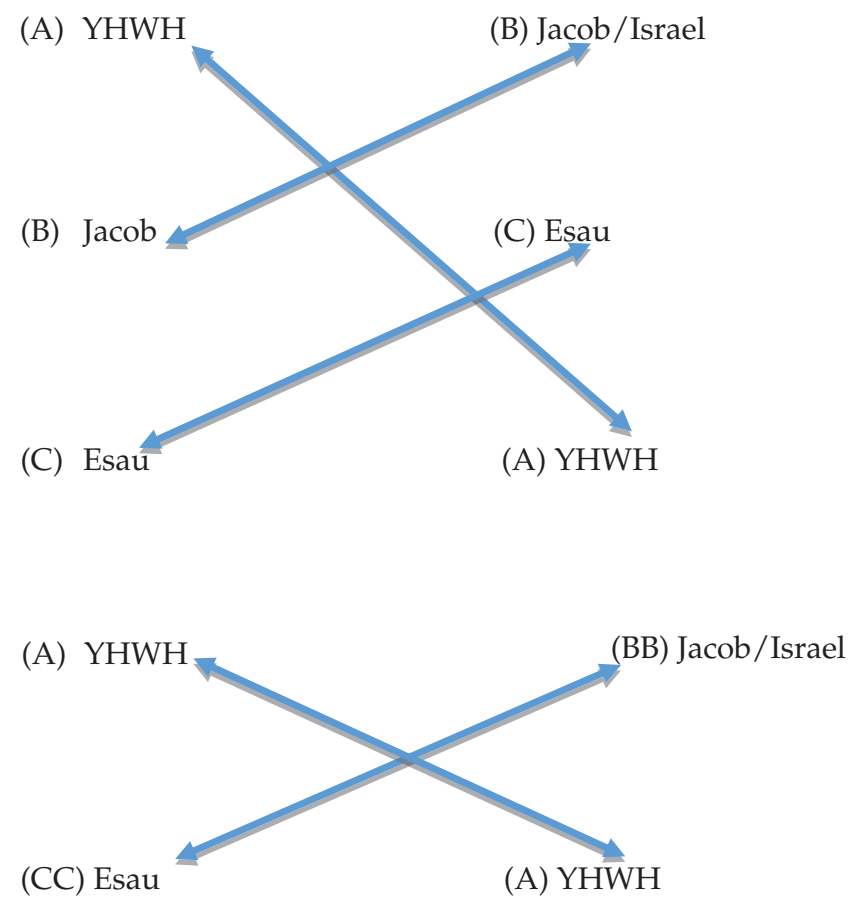

From the argumentation presented above it is clear that verses 2-5 form a complex and well-structured unit. At the same time the prominent chiastic structuring of the unit makes a process of gradual growth of the unit over a period of time unlikely. The chiastic structuring confirms the observation of Kessler (2011:108-109) that the unit deals with YHWH, Jacob/Israel and Esau/Edom in a triangular relationship. YHWH addresses Jacob/Israel directly while Esau/Edom is only indirectly addressed. There is no interaction between Jacob/Israel and Esau/Edom. The result of this observation is then that Malachi 1, 2-5 has two foci: YHWH's actions towards Jacob/Israel and secondly YHWH's actions against Esau/Edom. 


\section{Malachi 1:6-2:9}

The second unit is the most elaborate one in the book, comprising almost a third of the extent of the book. The theme dealt with in this unit addresses the sacrificial practices in postexilic Yehud.

The unit of 1:6-2:9 may be divided in two distinctive but yet connected parts, 1:6-14 and 2:1-9. The reason for this division is found in 2:1 where the priests are called upon in the vocative ('Now, this commandment is directed at you, o priests!'). The word attah (עתה), found at the beginning of verse 1 , is also an indication of a turning point in the argument presented against the priests. The remark by Kessler (2011) is important:

Nun hier in der Maleachi-Dichtung wird der Übergang so deutlich markiert. Dies geschieht zum einem durch der adverbiale Einleitung 'und jetzt' die sowohl in der epigraphischen Briefliteratur als auch in biblischen Texten den Übergang zu einer neuen, und zwar oft zur entscheidenden Aussage des Textes anzeigt. (p. 162)

Furthermore, it is noteworthy that words used at the beginning of the unit are now used for the first time again: $k b d$ (כבד) found in verse 6 occurs for the first time again in 2:2. In verse 6 mora'iy (מוראי) is read only to be found again in 2:5. Whereas 1:6-1:14 deals with sacrifices brought to $\mathrm{YHWH}$, nothing of that is mentioned in 2:1-2:9. Therefore, although 1:6-2:9 can be considered as a single unit, there is sufficient ground to argue for a two part division of this unit consisting of $1: 6-1: 14$ and $2: 1-2: 9$.

With verse 14 the first part of the pericope culminates in a curse. The person is indicated in the third person and that is a signal that the curse is not aimed at the priests in the first instance, but rather to the people bringing the offerings. Is it possible then that the people in general were part of the audience addressed by the prophet? The accusations levelled at the priests would then be heard not only by them but by the people as well. The corrupt sacrificial system affects thus both the priests as the overseers of proper worship as well as the people who bring the sacrifices.

The fear of YHWH's name mentioned in verse 14, harks back verse 6 where it is implied that YHWH should be feared, creating an inclusio. The question put in verse 6 is justified; there is indeed no fear of $\mathrm{YHWH}$ evident in the cult practiced in Jerusalem. Yet, at the same time, in an awkward way the question put in verse 6 is answered in an unexpected way: YHWH's name is feared 'among the nations', beyond the boundaries of the official cult practiced in Jerusalem.

Malachi 2:1 introduces a turning point in the argument presented. In 1:6-1:14 the prophet aimed his prophecy at the malpractices performed by the priests, now the very office of the priesthood is at stake. Whereas 1:6-1:14 focused on the sacrificial duties of the priests, this second part focuses more on the instruction and blessing the priests were supposed to give. Verses 1-2 can be seen as a hinge in the whole of the pericope that runs from 1:6-2:9. The priests are addressed again in the vocative as is the case in 1:6 and the issue of the honouring of the name of $\mathrm{YHWH}$ mentioned in 1:6 occurs again in 2:2.

\section{Malachi 2:10-2:16}

This unit should be seen as a unity, but can be clearly divided into two distinctive parts (verses 10-12; 13-16). Although it is sometimes argued that the two parts should rather consist of verses 10-13 and 14-16 (Kessler 2011:186), it is more likely to divide the unit between verses 12 and 13. In verse 10 the accusation is made that a 'man' acted unfaithfully and in verse 12 the wish is expressed that a 'man' should be cut off from the community creating an inclusio. Verse 13 opens with 'this secondly' z't seniyt (וזאת שנית) indicating a new turn and emphasis in the argument presented. In verses 10-12 the emphasiswasontheissueof(unmarried)menmarryingforeign women and the religious consequences of it whereas verses 13-16 deals with the related but yet distinguished issue of unfaithfulness against the wives men are already married to. The verb ksh (כסה) occurs in verse 13 only to reappear in verse 16 creating an inclusio thereby rounding verse 13-16 off as a subunit in this pericope.

A chiastic structure is displayed in the pericope: after a general introduction to the unit in verse 10, one finds:

- The offence committed, Judah acted treacherously bgd (בגד) (v. 11).

- The religious consequences, YHWH will cut off a man doing this (v. 12).

- (B1) The religious consequences, covering the altar with tears will be to no avail (v. 13).

- (A1) The offence committed, men have been unfaithful bgd (בגד) to their wives (vv. 14-16).

This third unit is also presented in a twofold way underlining two related but separate issues in terms of marriages between men and women.

\section{Malachi 2:17-3:7a ${ }^{2}$}

The issue at stake in this unit is the issue of the justice of God. 'Where is the God of justice' is the question put in Malachi $2: 17$. The question initially put by the people is answered in a surprising way. YHWH is and remains the God of justice. As proof of that He will come suddenly and firstly to his temple to be restored properly so that sacrifices can once again be brought in righteousness. Secondly, He will come to judge the people because of social transgressions apparent in society. YHWH has thus not changed as the initial question implied - he is still the God of justice. At the same time, the people are addressed as children of Jacob and they have not changed either. They still remain what they were from their very beginning, a sinful people who in spite of that have not been destroyed.

2.For an argumentation for this demarcation, see Snyman (2011:156-168). 
The twofold pattern followed is once again apparent. When the people questioned the justice of $\mathrm{YHWH}$, the startling answer was that justice pertains to both the cultic and ethic spheres of life.

\section{Malachi 3:7b-12}

The pericope commences with a statement structured in the form of a chiasm: (A) Turn (plural imperative) (B) to me (first person singular) and (B) I shall turn (first person singular) (A) to you (plural form). This is followed by a second chiasm: (A) Turn to me (B) says YHWH the Almighty and (B) you say in what way should (A) we turn? In this way a prominent introduction to the unit is created, binding the opening verse together in a unity. There is also a kind of an extended chiasm to be detected in v8b and v9b: (A) 'You are robbing (B) me'; (B) 'it is me that (A) you keep robbing'. With this chiasm a thought unit is communicated, driving home the idea of robbing God by withholding tithes, whilst in verse 10 a new element in the unit begins where the people are urged to rather bring the full tithe to the (temple) storehouse. Another chiasm was also detected in verses 10b-11:

- blessing as rain (10b A)

- rebuke of the devourer (11a B)

- consequences of the rebuke (11b B)

- consequences of the rain (11c A)(Weyde 2000:486-494).

The twofold way of presenting a prophetic oracle continues in this unit as well. In the first part (Ml 3:7b-10a) the people are accused of robbing God in terms of the tithes that were not brought in the proper way. In the second part the perspective changes to nature where $\mathrm{YHWH}$ may even be tested in bringing rain to secure crops. Neglected cultic practices are combined with ordinary life that has to do with crops being threatened by a drought.

\section{Malachi 3:13-3:21 (English translations 3:13-4:1-3)}

This unit is characterised by a striking symmetrical structure that can be schematised as follows, resulting in a two part division (vv. 13-16; 17-21; English 17-4:3)3:
A Righteous people (vv. 13-14)
B Evil people (vv. 15)
A Righteous people (vv.16)
A Righteous people (vv. 17-18)
B Evil people (vv. 19)
A Righteous people (vv. 20-21).

In verses 13-14 the complaint of the righteous people is taken up by the prophet. The words they uttered in a complaint that it is hard to serve God and live a pious life are considered as harsh by YHWH. Over against this situation of the righteous people stand the arrogant and proud people who are considered as evil-doers, testing God and even getting away with it. Verse 16 is all about

3.For an overview of views in this regard, see Snyman (1996:486-494). the God-fearers who are given a word of comfort amidst their situation of disillusionment with the current situation. Verses 17-21 constitute the second part of the pericope. Whereas the first part dealt with the present time and the unfortunate experiences of the believers, verses 17-21 (English 3:17-4:3) represent a shift to the future and open up an eschatological perspective to the society of Malachi's hearers. Verses 17-18 address the righteous people again whilst verse 19 speaks of the coming judgement on the arrogant people. Verses 20-21 (English 4:2-3) deal once again with the eventual outcome of God's intervention in their situation. The second unit in this pericope comes to a close with an inclusio as well as a chiasm that add another argument in favour of a two part division of the unit as a whole (3:13-16; 17-21; English 17-4:3):

Verse 17: 'says $\mathrm{YHWH}$ the Almighty (A) on the day I shall make' (B),

Verse 21: 'on the day I shall make (B'), says YHWH the Almighty' (A').

In this last unit of the book a double or twofold perspective can be seen. On the one hand there is a temporal perspective moving from the present to the future. The harsh and unpleasant present will be changed into a bright new future. At the same time the pious believers are contrasted with the proud and arrogant people. While the proud people are the ones who test God, challenge him and get away with it, it is the pious ones who suffer and even contemplate giving up believing at all. In the second part of the unit a complete reversal of roles is foreseen. The believers will enjoy exuberant deliverance while the proud ones will suffer utter and total destruction.

\section{Malachi 3:22-3:24 (English translations 4:4-4:6)}

Although not everybody would agree (Assis 2011:207-220; Floyd 2000; Glazier-McDonald 1987; Verhoef 1972), the conclusion of the book of Malachi in 3:22-3:24 is widely regarded as a later redactional addition (or additions) to Malachi 3:13-3:21 and, for that matter, to the rest of the book. There are obvious reasons for this observation. It seems odd that the characteristic question-answer style of dispute does not occur in the last three verses of the book. Secondly, the phrase so often used in the book (אמר יהוה צבאות) to mark divine speech is lacking in the last unit. Lastly, this last unit displays a use of language and style that is not found in the rest of the book. Scholars (Hill 1998; Horst 1964; Petersen 1995; Reventlow 1993) make mention of the decidedly Deuteronomistic language ('Horeb', 'all Israel', Moses as YHWH's servant, 'ordinances and statues') characteristic of this unit. The reference to the Torah of Moses, the designation of Moses as 'my servant', the reference to Horeb, the sending of Elijah on a reconciling mission to perhaps prevent a terrible ban of the land are unique and new issues raised that are not found in the rest of the book. The rather abrupt mention of the Torah of Moses after the announcement of the coming day of $\mathrm{YHWH}$ is an indication that something quite different is addressed now. Finally, the 
unit starts with an imperative which is another indication of a new beginning (cf. 3:7b).

It is also a matter of dispute whether Malachi 3:22-3:24 (English 4:4-4:6) in itself is not the result of two redactional additions, that is, Malachi 3:22 (English 4:4) and Malachi 3:23-3:24 (English 4:5-4:6). Some scholars think in terms of one addition (Glazier-McDonald 1987; Petersen 1995; Verhoef 1972) whilst others think in terms of two different additions (Rudolph 1976; Smith 1980). Verse 23 (English 4:5) does not begin with a waw connecting these two parts in a direct way. The prominent hinne (הנה) rather suggests a new beginning. The genre used in verse 22 (English 4:4) differs from that of the following two verses. In verse 22 (English 4:4) a 'Mahnung' is used whilst in verses 23-24 (English 4:5-4:6) a 'Gotteswort' in the form of an eschatological 'Heilswort' is used. It therefore seems more probable that we must think of two distinct additions.

The last part of the book confronts the reader with a text critical problem. In some manuscripts of the Septuagint (LXX) verse 22 is transposed to follow after verse 24 . Although this is the most obvious difference between the two versions, there are other differences as well as Ausloos (2014) made us aware of. However, taking only this major and obvious difference between the MT and LXX into account, it means that the last pericope of the book (according to the LXX) starts with the mentioning of the prophet Elijah and concludes with a reference to the Torah of Moses. The motivation for the change is said to soften the harsh way in which the Old Testament comes to an end predicting a ban on the land with a more positive one of an admonition to adhere to the Torah of Moses. Scholarly opinion is divided on whether or not to accept the rendering of the Septuagint or to retain the text as it is; in fact, it seems as if it is an impossible choice to make (Ausloos 2014). There is much to be said for the sequence of verses according to the Septuagint. The mentioning of a coming Day of the Lord in verse 23 neatly fits in with the theme of the Day of the Lord in the previous unit. The Day of the Lord announced in the previous unit (3:13-3:21; English 3:13-4:3) will now be preceded by the coming of Elijah. Verse 22 (English 4:4) will then serve as the climax of not only the book but also of the Corpus Propheticum as a whole.

In spite of all the difficulties this text presents us with, it is nevertheless interesting to note that the same twofold way of presenting the prophet's case is continued here. Two figures are mentioned. The Torah of Moses should be remembered and Elijah, the prophet, will come on a mission to reconcile fathers and children and vice versa.

\section{The macro structure of the book}

Does the book as a whole display a particular structure or pattern? This has been a topic discussed by scholars ending in a variety of viewpoints (Assis 2010; Clendenen 1987; Floyd 2000; Kessler 2011:51-53; Van Selms 1972; Wendland 1985:108-121). The content of the book displays the following structure:
A Malachi 1:1 Superscription: A message and a word from YHWH

B Malachi 1:2-5 From the past to the future contrasting Jacob/ Israel and Esau/Edom

C Malachi 1:6-2:9 Malpractices in the worship of Yahweh by the people and the priests

D Malachi 2:10-16 The issue of mixed marriages in worship and in marriage

$\mathrm{D}^{\prime}$ Malachi 2:17-3:7a The issue of the God of justice in the temple and social life

$\mathrm{C}^{\prime}$ Malachi 3:7b-12 Tithing as a cultic malpractice and the blessing to come

B' Malachi 3:13-21 A view from the present time to the future. A' Malachi 3:22-24 Postscript Two additions regarding Moses and Elijah.

From this structure it is clear that parts $\mathrm{D}$ and $\mathrm{D}^{\prime}$ form the core or centre of Malachi's oracles. It is also clear that the book as a whole can be divided into two distinctive parts (1:1-2:16 and 2:17-3:24 English 4:6 respectively) ${ }^{4}$. Not only does each unit consist of a twofold structure, the book also displays a twofold structure on a macro level.

According to Floyd (2000:568-572), the book can be divided into two sections. After an introduction in Malachi 1:2-1:5, two parts can be distinguished: Malachi 1:6-2:16 and Malachi 2:17-3:24. The first part can in itself be divided into two sections, a speech directed to the priests in Malachi 1:6-2:9 and a second section addressed to the people ( $\mathrm{Ml}$ 2:10-2:16). Both of these speeches are structurally parallel in form. Both begin with a prophecy of punishment (Ml 1:6-1:14; 2:10-2:12) announcing the penalty that is already in effect (Ml 1:10-1:14; 2:12) for a practice that profanes the cult (Ml 1:6-1:9; $2: 10-2: 11)$. Both conclude with a prophetic call to repentance (Ml 2:1-2:9; 2:13-2:16), urging the addressees to behave in a way that avoids profanation of the cult. The second part of the book (Ml 2:17-3:24; English 4:6) also consists of two speeches, this time directed to the people as a whole (Ml 2:17-3:12; Ml 3:13-3:24; English 3:13-4:6). The first speech (Ml 2:17-3:12) is a prophetic call to repentance with a call to the people to turn away from the attitude expressed in such discourse and to contribute to the support of the newly reformed temple cult. The second speech (Ml 3:13-3:24; English 4:6) is a prophetic report of how one group turned from cynical talk and began to engage the covenant traditions.

\section{Conclusion}

Viewing the different parts that make up the book, it is clear that the different units or pericopes are time and again structured in two parts. The superscription in Malachi 1:1 consists of an initial heading followed by an extended one. Malachi 1:2-1:5 deals with the respective fates of Jacob/ Israel and Esau/Edom. In Malachi 1:6-2:9 the emphasis is on malpractices in the sacrificial system (1:6-1:14) and within the priesthood itself (2:1-2:9). Malachi 2:10-2:16 deals with the effects mixed marriages have on the worship of YHWH

4.The similarities with the concentric structure proposed by Kessler (2011:53) as well as the results of Assis's (2010; 2011) investigation are striking, although with different arguments offered in each case. 
(2:10-2:12) and with the unfaithfulness of men towards their wives (2:13-2:16). Malachi 2:17-3:7a answers the question of the apparent absence of the God of justice by pointing out his imminent coming to judge both the temple $(3: 1-3: 4)$ and the social behaviour of the people (3:5-3:7a). Malachi $3: 7 b-3: 12$ is all about tithing $(3: 7 b-3: 9)$ and the blessing that may be expected from YHWH (3:10-3:12). Malachi 3:13-3:21 (3:13-4:3) deals with the current distress of the fearers of YHWH (3:13-3:16) and the future awaiting them (3:17-3:21; $3: 17-4: 3)$. The last unit of the book deals with Moses (3:22; 4:4) and Elijah (3:23-3:24; 4:5-4:6). Sufficient proof has been given to sustain the initial hypothesis. Viewing the book from a holistic perspective it becomes clear that the book is structured by constantly making use of a twofold pattern in each of the different units of the book. It is also remarkable that each unit has a horizontal (human) and vertical (divine) perspective intertwined with one another. Cultic and ethical matters are treated not in an either/or way, but rather as two sides of the same coin, co-existing alongside one another. It has also been argued that on a macro level the book displays a twofold division comprising of Malachi 1:1-2:16 and 2:17-3:24 respectively. The results with this investigation are in agreement with similar investigations of Assis, Kessler and Floyd that came to the same result, namely that the book of Malachi can be divided into two distinct parts consisting of Malachi 1:1-2:16 and 2:17-3:24 (English 4:6) respectively.

If these observations are valid, it adds another argument strengthening recent trends in the research of the book of Malachi indicating that the book was written with little room for extensive redactional activity. The twofold structure also has implications for the theological understanding of the book as a whole. The relationship with YHWH made visible through sacrifices is equally important to matters on the level of human relationships $(2: 10-2: 16 ; 2: 17-3: 7 a)$. Priests and lay people are addressed (1:6-2:9). The past and the present are addressed at the beginning of the book (1:2-1:5). At the end of the book the present and the future are addressed (3:13-3:22 English 3:13-4:3). Examining the overall structure of a book does contribute to the understanding of the book as a whole as well as the different parts that make up the book.

\section{Acknowledgements Competing interests}

The author declares that he has no financial or personal relationships which may have inappropriately influenced him in writing this article.

\section{References}

Assis, E., 2010, 'Structure and meaning in the book of Malachi', in J. Day (ed.), Prophecy and prophets in ancient Israel, pp. 354-369, T \& T Clark International, New York, NY,

Assis, E., 2011, 'Moses, Elijah and the Messianichope. Anew reading of Malachi3.22-24', Zeitschrift für die alttestamentliche Wissenschaft 123(2), 207-220. http://dx.doi. org/10.1515/zaw.2011.013

Ausloos, H., 2014, 'Mal 3:22-24 (4:1-6) in Hebrew and Greek. Some remarks concerning its function in the canon', in T.M. Law, K. De Troyer \& M. Liljeström concerning its function in the canon', in T.M. Law, K. De Troyer \& M. Liljeström
(eds.), In the footsteps of Sherlock Holmes. Studies in the Biblical Text in honour of (eds.), In the footsteps of Sherlock Holmes. Studies in
Anneli Aejmelaus, pp. 479-493, Peeters, Louvain,

Baldwin, J.G., 1978, Haggai, Zechariah, Malachi: An introduction and commentary, Inter-Varsity Press, Leicester. (Tyndale Old Testament Commentary).

Clendenen, E.R., 1987, 'The structure of Malachi: A textlinguistic study', Criswell Theological Review 2, 3-17.

Clendenen, E.R., 2004, Malachi, Broadman \& Holman Publishers, Nashville, TN. (New American Commentary).

De Boer, P., 1948, 'An inquiry into the meaning of the term Massa', Orthodox Theological Studies 5, 197-214.

Elliger, K., 1975, Das Buch der zwölf kleinen Propheten II, Vandenhoeck \& Ruprecht, Göttingen.

Floyd, M.H., 2000, Minor Prophets. Part 2, William B. Eerdmans Publishing Company, Grand Rapids, MI.

Glazier-McDonald, B., 1987, Malachi the divine messenger, Scholars Press, Atlanta, GA. (SBLDS 98).

Hieke, T., 2006, Kult und Ethos. Die Verschmelzung von rechtem Gottesdienst und gerechtem Handln im Lesevorgang der Maleachischrift, Verlag Katholisches Bibelwerk GmbH, Stuttgart. (SBS 208)

Hill, A.E., 1998, Malachi: A new translation with introduction and commentary, Doubleday (Anchor Bible), New York, NY.

Horst, F., 1964, Die zwölf kleinen Propheten Nahum bis Maleachi, 3. Auflage. J.C.B. Mohr, Tübingen. (HAT 14).

Kessler, R., 2011, Maleachi, Verlag Herder GmbH, Freiburg (Herders Theologischer Kommentar zum Alten Testament).

Meinhold, A., 2006, Maleachi, Neukirchen-Vluyn, Neukirchener (BKAT Band XIV/8).

Petersen, D.L., 1995, Zechariah 9-14 and Malachi. A commentary, Westminster John Knox Press, Louisville, KY.

Reventlow, H.G., 1993, Die Propheten Haggai, Sacharja und Malachi, Vandenhoeck \& Ruprecht, Göttingen. (ATD 25/2).

Ridderbos, J., 1935, De kleine profeten III, Kok, Kampen (Korte Verklaring der Heilige Schrift).

Rudolph, W., 1976, Haggai - Sacharja 1-8 - Sacharja 9-14 - Maleachi, Gütersloher Verlagshaus, Gerd Mohn. (KAT 13/4).

Smith, J.M.P., 1980, A critical and exegetical commentary on the book of Malachi, T\&T Clark Ltd., Edinburgh. (ICC).

Snyman, S.D., 1986, 'Antitheses in Mal 1,2-5', Zeitschrift für die alttestamentliche Wissenschaft 98, 436-438.

Snyman, S.D., 1996, 'A structural approach to Mal 3:13-21', Old Testament Essays 9(3), 486-494.

Snyman, S.D., 2011, 'Rethinking the demarcation of Malachi 2:17-3:5', Acta Theologica 31(1), 156-168. http://dx.doi.org/10.4314/actat.v31i1.9

Van der Woude, A.S., 1982, Haggai Maleachi, Callanbach, Nijkerk. (POT).

Van Selms, A., 1972, 'The inner cohesion of the book of Malachi', in W.C. van Wyk (ed.), Studies in Old Testament Prophecy, Proceedings of the Ou Testamentiese Werkgemeenskap van Suid-Afrika 1971, pp. 27-40, Pro Rege, Potchefstroom.

Verhoef, P.A., 1972, Maleachi, Kok, Kampen.

Wendland, E.R., 1985, 'Linear and concentric patterns in Malachi', The Bible Translator 36(1), 108-121.

Weyde, K.W., 2000, Prophecy and teaching. Prophetic authority, form problems and the use of traditions in the book of Malachi, Walter de Gruyter, Berlin. (BZAW 288). http://dx.doi.org/10.1515/9783110811780

Willi-Plein, I., 2007, Haggai, Sacharja, Maleachi, Theologischer Verlag, Züricher Bibelkommentare, Zürich. 